Acta Regionalia et Environmentalica 2

Nitra, Slovaca Universitas Agriculturae Nitriae, 2015, pp. 30-37

\title{
POTENTIALS FOR AGRO-ENERGY CROPS PRODUCTION: EXAMPLE OF MISCANTHUS CULTIVATION IN SERBIA
}

\author{
Gordana DRAŽIĆ1*, Mirjana ARANĐELOVIĆ', Jelena MILOVANOVIĆ', \\ Zuzana JUREKOVÁ2, Eleonóra MARIŠOVÁ2 \\ 'Singidunum University Belgrade, Republic of Serbia \\ ${ }^{2}$ Slovak University of Agriculture in Nitra, Slovak Republic
}

\begin{abstract}
In accordance with priorities of sustainable development in Serbia, production and use of biomass is crucial for provision of annually renewable national sources of energy and for environmental quality conservation. Rural development has typically focused on improving agricultural production and promoting market orientation, however, as the examples of other countries in the EU accession process have shown (e.g. Slovakia), such an approach could threaten the survival of rural population. Biomass production is one of the key sectors with significant potential for diversification of rural economy. The results of multiannual research work supported by the Ministry of Education, Science and Technological Development of the Republic of Serbia through national scientific projects and several international initiatives are summarized in this paper. The research activities focus on Miscanthus $\times$ giganteus Greef et Deu. The production potentials of miscanthus on fertile and degraded soils were investigated since 2009 in experimental plots established on moderate and extremely degraded lands in Serbia, applying various agrotechnical measures in different ecological conditions. The results show that fertile agricultural land as well as moderate degraded areas provide suitable conditions for miscanthus biomass and viable rhizomes production for energy and ecoremediation purposes.
\end{abstract}

Keywords: agro-energy crops, degraded soil, growing parameters, yield, ecoremediation

The area of degraded land in Serbia is 35,000 ha, while the total area of unused arable land reaches up to 250,000 ha $(4.9 \%$ of the total arable land). National Action Plan for renewable energy of the Republic of Serbia planned defining and introducing of regular practice of incentives for designated land use for energy purposes. Unused and degraded lands could be used for crops production, especially for high productive agroenergy crops like Miscanthus, for energy and ecoremediation purposes, in accordance with the objectives of the Directive on renewable energy for the EU and the Law on Energy of the Republic of Serbia. It could provide a chance for rural development, decrease of energy dependency, poverty reduction and reduction of greenhouse gas emissions.

The use of renewable energy sources is one of the key components of sustainable development which enables rational economic, environmental and social effects. Support for the development of renewable energy is becoming an important goal within the European Union. Through the Directive on renewable energy sources, the European Union has set itself the objective of increasing the share of renewables in the energy mix to $20 \%$ by 2020 . The Law on Energy of the Republic of Serbia from 2014 has defined measures and activities taken for achieving long-term goals, and measures and activities: creating economic, commercial and financial conditions for the production of energy from renewable sources and combined production of electricity and heat as well as creating conditions for the use of new energy sources.
The development of renewable energy resources is the object of interest at the EU level and national level (Jureková and Maršalová, 2008). Various support measures have been adopted in the EU member states. Support policy became the part of the Rural Development Programme 2014-2020 in Slovakia. Within this document, renewable energy resources become the part of the second goal of the Rural Development Programme 2014-2020: sustainable management of natural resources and adaptation on climate change, within the scope of the second priority: increased proportion of biomass and waste, crop residues, livestock excreta and other renewable energy sources for energy production.

There has been a long-standing trend of increasing energy dependence of the Republic of Serbia. Projected import dependence in 2014 was 36.31\% (Energy Balance of the Republic of Serbia for 2014). It is estimated that the imported part in the final energy consumption through decades will slowly grow, and that, in accordance with the development strategy of the Republic of Serbia until 2025 with projections to 2030, it will reach 37.4 percent in 2030. According to estimates from the World Energy Outlook of 2014, the demand for primary energy is expected to increase by 37 percent until 2040, provided that natural gas consumption will increase by 50 , and oil by ten percent. According to data from the National Action Plan for renewable energy sources of the Republic of Serbia from 2009, there were no agro-energy crops planted for biomass production on the territory of the Republic of Serbia. 
Considering the facts mentioned above as well as the clearly defined objective of increasing the production of renewable energy, the Research and Development Centre of the Faculty of Applied Ecology in 2011 formed the experimental fields of agro-energy crop Miscanthus $\times$ giganteus. The goal of the research centre was the formation of network of scientific polygons which would carry out research on the cultivation possibility of Miscanthus as well as the induction of agricultural practices in line with the objectives of the Strategy of agriculture and sustainable development, to ensure: improvement of the quality of life in rural areas and poverty reduction; sustainable resource management and environmental protection; adaptation and mitigation of climate change impacts; raising awareness of the importance of renewable energy and the production of energy crops; efficient management of public policies and improvement of the institutional framework for the development of agriculture and rural areas; diversification of rural economy; improvement of soil fertility; reduction of loss and land degradation; permanent monitoring of soil quality. The aim of this paper is to summarize results of multiannual research work supported by the Ministry for Education, Science and Technological Development of the Republic of Serbia through national scientific projects and several international initiatives

\section{Material and methods}

A network of Miscanthus experimental polygons has been established in Serbia and it included seven different locations. Experimental fields are selected depending on the type of soil:

1. Zemun /chernozem ( $\left.44^{\circ} 51^{\prime} 14.20^{\prime \prime} \mathrm{N}, 20^{\circ} 22^{\prime} 39.97^{\prime \prime} \mathrm{E}\right)$.

2. Zasavica / hydromorphic black soil, humogley $\left(44^{\circ} 57^{\prime}\right.$ $38.73^{\prime \prime} \mathrm{N}, 19^{\circ} 33^{\prime} 2.68^{\prime \prime} \mathrm{E}$ ).

3. Ralja / etrustic cambisol ( $44^{\circ} 34^{\prime} 18.00^{\prime \prime} \mathrm{N}, 20^{\circ} 22^{\prime} 29.51^{\prime \prime}$ E).

4. Kozjak, Loznica municipality $44^{\circ} 35^{\prime} 7^{\prime \prime} \mathrm{N}, 19^{\circ} 17^{\prime} 2^{\prime \prime} \mathrm{E}^{\circ}$.

5. Vršac, fertile soil, carbonated chernozem $44^{\circ} 6^{\prime} 18.44^{\prime \prime} \mathrm{N}$, $\left.21^{\circ} 18^{\prime} 7.2^{\prime \prime} \mathrm{E}\right)$.

6. TENT B, Obrenovac municipality, ash landfill ( $44^{\circ} 65^{\prime}$ $49.78^{\prime \prime} \mathrm{N}, 20^{\circ} 00^{\prime} 16.58^{\prime \prime} \mathrm{E}$ ).

7. Mining basin Kolubara, East field, Lazarevac municipality $\left(44^{\circ} 28^{\prime} 16.41^{\prime \prime} \mathrm{N}, 20^{\circ} 14^{\prime} 59.62^{\prime \prime} \mathrm{E}\right)$.

A set of biomorphological parameters was established and was monitored at all experimental fields. The following parameters were monitored once a month:

1. Height of the crop.

2. Total number of leaves.

3. Number of green leaves.

4. Number of dried leaves.

5. Width and length of the green part of the leaf.

6. Tillering.

The diameter and the length of the leaves were measured at the fourth leaf of the stem. The effects of increasing doses of mineral fertilizers on the crop morphological characteristics, the ability of growing on moderate and extreme degraded soils and possibility of heavy metals application were studied. Miscanthus' heavy metals absorption capacity was analyzed by adding $250 \mathrm{ml}$ cadmium chloride solution concentration $228.4 \mathrm{ppm}\left(57.1 \mathrm{mg} \mathrm{CdCl}_{2}\right.$ ) and $250 \mathrm{ml}$ of nickel chloride concentration of 518.8 ppm (129.7 mg $\mathrm{NiCl}_{2}$ ) in the substrate in experimental vessels. Treatment of rhizome with growth stimulator was also made by adding $90 \mathrm{ppm}$ of acetylsalicylic acid. Presentation of results represents average of three measures.

Miscanthus rhizomes were obtained from registered Austrian manufacturer "Miscanthus giganteus produstion". Planting material has been stored in a dark room, dew prevented rhizomes from drying out. Planting of rhizomes was performed at the beginning of April 2011. Rhizomes at the length of $10-15 \mathrm{~cm}$ with 3-6 nodes were manually planted at the depth of about $10 \mathrm{~cm}$. Planting density varied from 1 to 3 rhizomes per square meter in different experimental plots. Shortly before the planting, soil disking was carried out and $10 \times 10 \mathrm{~m}$ plots were formed. Mineral fertilizers were used for mineral nutrition (NPK $15: 15: 15$ ). In the first year, the crop fertilization was carried out in June. In the second year, depending on the treatment, fertilizing was performed in two terms, just before the start of the vegetation period at the end of February and in the middle of the growing season at the end of June. Suppression of weed species was carried out mechanically and using the mixture of herbicides: Calyisto, Harmony, Atplus, Trend, in the first year. In the second year of development, there were no applied measures for weed suppression.

The analysis of experimental data was performed using the statistical package SPSS (IBM SPSS Version 21.0).

\section{Results and discussion}

\section{Monitoring of development and changes of Miscanthus giganteus morpho-physiological characteristics}

Germination in the first year started 10-15 days after planting. Uneven initial development of plants and formation of a small number of stems are noticeable depending on the treatment. The germination rate was $88 \%$. In the early stages of crop development, number of stems varies considerably (DANALATOS et al., 2007); in the middle of the vegetation period, the average was 8-19 stems. $\mathrm{m}^{-2}$. Only the treatment with planting density of 3 rhizomes. $\mathrm{m}^{-2}$ achieved $100 \%$ of area coverage. By the end of July and early August, all experimental plots were completely covered with biomass, except of the experimental treatment with no agro practices and planting rhizomes with density of $2 \mathrm{~m}^{-2}$, where the coverage reached $20-40 \%$. According to the Chi-square test, plantation density had no impact on the percentage of area coverage (Table 1 and Table 2).

Chi-square test results indicate that the density of planting also does not affect the percentage of Miscanthus germination (Table 2 and Table 3 ).

By applying $t$-test, it was found that the application of agro-technical measures affects the plant coverage while there is no connection between the percentage of germination of Miscanthus and agricultural practices (Table 5).

The average height of Miscanthus in the second year of development was the highest in the experimental 
Table 1 and 2 The influence of planting density on the percentage of area coverage

\begin{tabular}{|c|c|c|c|c|c|}
\hline & & \multicolumn{3}{|c|}{ Percent of coverage } & \multirow[t]{2}{*}{ Tota } \\
\hline & & 39 & 98 & 100 & \\
\hline \multirow{3}{*}{ Number of rhisomes per $\mathbf{m}^{2}$} & 1 & 0 & 1 & 0 & 1 \\
\hline & 2 & 1 & 0 & 1 & 2 \\
\hline & 3 & 0 & 0 & 1 & 1 \\
\hline \multicolumn{2}{|l|}{ Total } & 1 & 1 & 2 & 4 \\
\hline
\end{tabular}

\section{Chi-Square Tests}

\begin{tabular}{|l||c|c|c|}
\hline & Value & df & Asymp. Sig. (2-sided) \\
\hline \hline Pearson Chi-Square & $5.000^{\mathrm{a}}$ & 4 & 0.287 \\
\hline Likelihood Ratio & 5.545 & 4 & 0.236 \\
\hline Linear-by-Linear Association & 0.002 & 1 & 0.963 \\
\hline N of Valid Cases & 4 & - & - \\
\hline
\end{tabular}

Table 3 and 4 The influence of planting density on the Miscanthus percentage of sprout

\begin{tabular}{|c|c|c|c|c|c|c|}
\hline & & \multicolumn{4}{|c|}{ Percent of sprout } & \multirow[t]{2}{*}{ Tota } \\
\hline & & 82 & 83 & 85 & 86 & \\
\hline \multirow{3}{*}{ Number of rhisomes per $\mathbf{m}^{2}$} & 1 & 0 & 1 & 0 & 0 & 1 \\
\hline & 2 & 1 & 0 & 1 & 0 & 2 \\
\hline & 3 & 0 & 0 & 0 & 1 & 1 \\
\hline \multicolumn{2}{|l|}{ Total } & 1 & 1 & 1 & 1 & 4 \\
\hline
\end{tabular}

\section{Chi-Square Tests}

\begin{tabular}{|l||c|c|c|}
\hline & Value & df & Asymp. Sig. (2-sided) \\
\hline \hline Pearson Chi-Square & $8.000^{\mathrm{a}}$ & 6 & 0.238 \\
\hline Likelihood Ratio & 8.318 & 6 & 0.216 \\
\hline Linear-by-Linear Association & 1.350 & 1 & 0.245 \\
\hline N of Valid Cases & 4 & - & - \\
\hline
\end{tabular}

Table 5 The influence of agricultural measures on the percentage of the plant coverage

\begin{tabular}{|l||c|c|c|c|c|}
\hline & Agricultural measures & N & Mean & Std. deviation & Std. Error Mean \\
\hline \hline \multirow{2}{*}{ Percent of coverage } & yes & 3 & 0.9933 & 0.01155 & 0.00667 \\
\cline { 2 - 6 } & no & 2 & 0.3400 & 0.07071 & 0.05000 \\
\hline \multirow{3}{*}{ Percent of sprout } & yes & 3 & 0.8467 & 0.01528 & 0.00882 \\
\cline { 2 - 6 } & no & 2 & 0.5800 & 0.04243 & 0.03000 \\
\hline
\end{tabular}

Independent Samples Test

\begin{tabular}{|c|c|c|c|c|c|c|c|c|c|c|}
\hline & & \multicolumn{2}{|c|}{$\begin{array}{l}\text { Levene's Test for } \\
\text { Equality of Variances }\end{array}$} & \multicolumn{7}{|c|}{$t$-test for Equality of Means } \\
\hline & & \multirow[t]{2}{*}{$\mathbf{F}$} & \multirow[t]{2}{*}{ Sig. } & \multirow[t]{2}{*}{$\mathbf{t}$} & \multirow[t]{2}{*}{ df } & \multirow[t]{2}{*}{$\begin{array}{c}\text { Sig. } \\
\text { (2-tailed) }\end{array}$} & \multirow[t]{2}{*}{$\begin{array}{c}\text { Mean } \\
\text { difference }\end{array}$} & \multirow[t]{2}{*}{$\begin{array}{l}\text { Std. Error } \\
\text { difference }\end{array}$} & \multicolumn{2}{|c|}{$\begin{array}{l}\text { 95\% Confidence } \\
\text { interval of the } \\
\text { difference }\end{array}$} \\
\hline & & & & & & & & & lower & upper \\
\hline \multirow{2}{*}{$\begin{array}{l}\text { Percent } \\
\text { of coverage }\end{array}$} & $\begin{array}{l}\text { Equal variances } \\
\text { assumed }\end{array}$ & - & - & 45.250 & 2 & 0.000 & 0.60333 & 0.01333 & 0.54596 & 0.66070 \\
\hline & $\begin{array}{l}\text { Equal variances } \\
\text { not assumed }\end{array}$ & - & - & - & - & - & 0.60333 & - & - & - \\
\hline \multirow{2}{*}{ Percent of sprout } & $\begin{array}{l}\text { Equal variances } \\
\text { assumed }\end{array}$ & - & - & 1.512 & 2 & 0.270 & 2.667 & 1.764 & -4.922 & 10.256 \\
\hline & $\begin{array}{l}\text { Equal variances } \\
\text { not assumed }\end{array}$ & - & - & - & - & - & 2.667 & - & - & - \\
\hline
\end{tabular}


treatment with the $1 \mathrm{~m}^{-2}$ planting density. With the increase of plantation density and nitrogen rate, the number of stems. $\mathrm{m}^{-2}$ increases and the height of the crop and intensity of tillering decrease, which is in line with the results presented in Dražić et al., (2012), according to which the plot with the highest density of planting rhizomes $3 \mathrm{~m}^{-2}$ gave the lowest crops. The amount of applied nitrogen had no effect on stems height (Christian et al., 2008; Clifton-Brown et al., 2001).

The application of nitrogen fertilizer affected the strength of tillering, but there is no statistically significant relationship between the amount of ingested nitrogen and tillering power (Table 6).

The intensity of tillering, forming of new stems from a rhizome (the number of stems/rhizome) slightly increases with the amount of nitrogen. The dynamics of tillering decreases with increasing density. The largest number of newly established stems per vital rhizome was recorded at the plot with the lowest density of planting $1 \mathrm{~m}^{-2}$. In relation to the amount of nitrogen fertilizer of $50 \mathrm{~kg} \mathrm{ha}^{-1}$, largest number of stems has been formed at 2 rhizomes. $\mathrm{m}^{-2}$ planting density. The obtained results are comparable with literature data for Miscanthus production on low quality soils (Zivanovic et al., 2014; Ikanovic et al., 2015a; 2015b).

Individual living space is a cardinal determinant in terms of making biomass of the Miscanthus. That affects the gradual expansion of underground organs. In conditions of Slovakia, the cultivation of Miscanthus plantation without application of nitrogen and establishment of the plantation -1 rhizomes per square meter, detailed research was conducted at the site in Kolíňany (southwestern Slovakia). Kotrla and Prčík, (2013) and Prčík and Kotrla (2013) studied the impact of expansion of Miscanthus tillering to produce aboveground biomass. Since the founding of Miscanthus plantations in conditions of southwestern Slovakia in 2010, we observed the annual accretion in tillering of individuals Miscanthus. In early 2015, after the fifth growing season, we recorded an average size of tillering at $857 \mathrm{~mm}$. The average annual increase in the size of the tillering is $21 \%$. The number of stems reduces with growing tillering during the growing season. Failure of the number of stems is reflected inside of the tillering. As reported by Kotrla and Prčík (2014), the reason for this decline is competition of the individual plant for environmental conditions (mainly light). Creation of new stems will run from circuit tillering. Stems that grow from the center of the tillering are limited by lack of radiation. The rate of stem growth from the edge of the circle tillering creates competitive advantage within the individual. Therefore, with increased height of stems, the stems localized in the middle of the tillering with the lower height start to wither.

It has been observed that plants freeze only at the experimental plots that are located near the irrigation diTch, due to high groundwater levels. During the first winter, Miscanthus freezing rate was $4 \%$. In the second year of development there were no consequences from the frost. Moisture content depends primarily on the climatic conditions and the amount of applied nitrogen. Increasing doses of nitrogen increase the moisture content in the biomass (Dražić et al., 2014). High moisture content in Miscanthus is characteristic for intensive growth period, from May to September (Dražić et al., 2010). The results are consistent with the findings of Lewandowski et al. (2000), who stated that moisture content of $70 \%$ in November reduces to $20 \%$ in March.

In the first year of development, the temperature went down to $-26{ }^{\circ} \mathrm{C}$. Although Miscanthus was described as extremely sensitive to cold (Ježowski, 1994), it resisted

Table 6 The influence of nitrogen fertilizer on the percentage of the plant coverage

\begin{tabular}{|l||c|c|c|c|c|}
\hline & Fertilizer & N & Mean & Std. deviation & Std. Error Mean \\
\hline \hline \multirow{2}{*}{$\begin{array}{l}\text { Intensity of the crop } \\
\text { tillering - may }\end{array}$} & yes & 6 & 30.33 & 5.203 & 2.124 \\
\cline { 2 - 6 } & no & 3 & 9.67 & 2.517 & 1.453 \\
\hline $\begin{array}{l}\text { Intensity of the crop } \\
\text { tillering- november }\end{array}$ & yes & 6 & 33.17 & 6.210 & 2.535 \\
\cline { 2 - 6 } & no & 3 & 14.33 & 3.055 & 1.764 \\
\hline
\end{tabular}

\section{Independent Samples Test}

\begin{tabular}{|c|c|c|c|c|c|c|c|c|c|c|}
\hline & & \multicolumn{2}{|c|}{\begin{tabular}{|c|} 
Levene's Test for \\
Equality of Variances
\end{tabular}} & \multicolumn{7}{|c|}{$t$-test for Equality of Means } \\
\hline & & \multirow[t]{2}{*}{$\mathbf{F}$} & \multirow[t]{2}{*}{ Sig. } & \multirow[t]{2}{*}{$\mathbf{t}$} & \multirow[t]{2}{*}{ df } & \multirow[t]{2}{*}{$\begin{array}{c}\text { Sig. } \\
\text { (2-tailed) }\end{array}$} & \multirow[t]{2}{*}{$\begin{array}{c}\text { Mean } \\
\text { difference }\end{array}$} & \multirow[t]{2}{*}{$\begin{array}{l}\text { Std. Error } \\
\text { difference }\end{array}$} & \multicolumn{2}{|c|}{$\begin{array}{l}\text { 95\% Confidence } \\
\text { interval of the } \\
\text { difference }\end{array}$} \\
\hline & & & & & & & & & lower & upper \\
\hline \multirow{2}{*}{$\begin{array}{l}\text { Intensity } \\
\text { of the crop } \\
\text { tillering - May }\end{array}$} & $\begin{array}{l}\text { Equal variances } \\
\text { assumed }\end{array}$ & 1.626 & 0.243 & 6.356 & 7 & 0.000 & 20.667 & 3.251 & 12.978 & 28.355 \\
\hline & $\begin{array}{l}\text { Equal variances } \\
\text { not assumed }\end{array}$ & & & 8.031 & 6.963 & 0.000 & 20.667 & 2.573 & 14.575 & 26.758 \\
\hline \multirow{2}{*}{$\begin{array}{l}\text { Intensity of the } \\
\text { crop tillering - } \\
\text { November }\end{array}$} & $\begin{array}{l}\text { Equal variances } \\
\text { assumed }\end{array}$ & 0.966 & 0.358 & 4.845 & 7 & 0.002 & 18.833 & 3.887 & 9.643 & 28.024 \\
\hline & $\begin{array}{l}\text { Equal variances } \\
\text { not assumed }\end{array}$ & & & 6.098 & 6.944 & 0.001 & 18.833 & 3.089 & 11.518 & 26.148 \\
\hline
\end{tabular}


Table 7 Losses of Miscanthus in the first year of development

\begin{tabular}{|l||c|c|c|c|}
\hline Experimental size & Degree of emerge in \% & Summer damage in \% & Winter freezing damage in \% & Late frost damage in \% \\
\hline \hline Zemun & $92(72-96)$ & $5(2-10)$ & $5(3-7)$ & $14(5-20)$ \\
\hline Ralja & $90(85-95)$ & $5(2-9)$ & $10(5-12)$ & $12(5-15)$ \\
\hline Loznica & $86(70-90)$ & $5(3-11)$ & $2(0-3)$ & $3(1-5)$ \\
\hline Zasavica & $84(80-92)$ & $5(3-12)$ & $2(0-3)$ & $5(0-11)$ \\
\hline
\end{tabular}

Table 8 Moisture contents

\begin{tabular}{|c|c|c|c|c|}
\hline Experimental size & $\begin{array}{c}\text { Moisture content } \\
\text { EH } \\
0 \\
\end{array}$ & $\begin{array}{c}\text { Moisture content } \\
\text { EH } \\
\text { WF }\end{array}$ & $\begin{array}{c}\text { Moisture content } \\
\text { LH } \\
0 \\
\end{array}$ & $\begin{array}{c}\text { Moisture content } \\
\text { LH } \\
\text { WF }\end{array}$ \\
\hline Zemun & $80 \pm 7$ & $89 \pm 6$ & $18 \pm 2$ & $20 \pm 4$ \\
\hline Ralja & $79 \pm 7$ & $85 \pm 5$ & $20 \pm 2$ & $20 \pm 3$ \\
\hline Loznica & $66 \pm 9$ & $74 \pm 3$ & $18 \pm 3$ & $21 \pm 4$ \\
\hline Zasavica & $82 \pm 4$ & $86 \pm 5$ & $24 \pm 2$ & $27 \pm 4$ \\
\hline
\end{tabular}

the winter with very low losses. Losses of Miscanthus in the first year of development were from 3 to 14 percent (Table 7).

Moisture content in the function of harvest timing was also analyzed. It appears that the latest harvest provides smaller moisture content (Table 8).

\section{Yields}

The maximum biological yield of Miscanthus is recorded at the beginning of October while the harvest in February has an average yield reduction from 31.7 to $38.5 \%$, depending on the treatment. Ascending dose of nitrogen slightly increases the yield at all planting densities (without statistical significance). Long retention of leaves on the stem was observed on the plots with a greater amount of applied nitrogen, it also contributes to reducing the pre-harvest losses (Dželetović et al., 2010). The findings are in line with Danalatos et al. (2007), who stated the biggest recorded yields with fertilizer and with irrigation.

The highest dry matter yield in the second year was achieved in the treatment with 2 rhizomes $\mathrm{m}^{-2}$ density and nitrogen rate of $50 \mathrm{~kg} \mathrm{ha}^{-1}$ with irrigation of four times during summer. As we have expected, the best results were achieved on fertile soil. Cropyields in the first year range from $1-2 \mathrm{tha}^{-1}$, in the second year 4-10 tha $\mathrm{ha}^{-1}$, and in the third year 10-13 t ha-1. Unexpectedly big yields were accomplished on

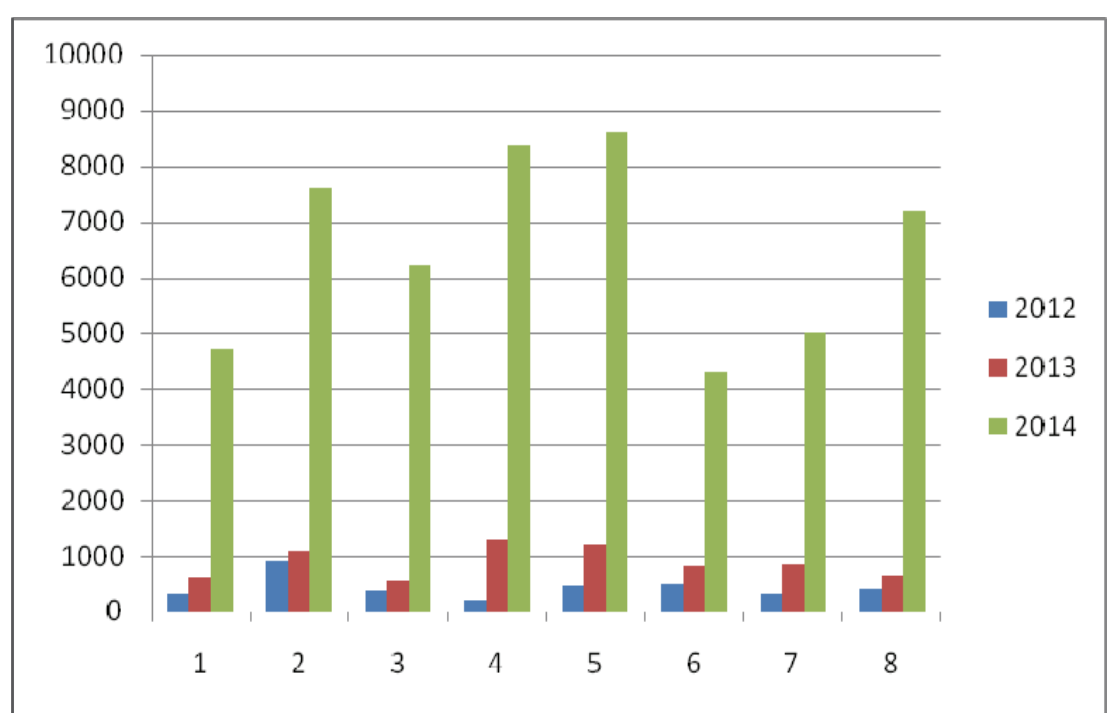

Figure 1 Yields during three years on the overburden soil from mining basin in Kolubara

experimental fields established in Zasavica and mining basin Kolubara.

The soil in Zasavica is classified as humogley. These are deep black soils, with poorer physical characteristics, mostly hydrogen, heavy in texture, with clay content over $60 \%$. High relative humidity and high groundwater levels (1.5-2 m) provide ideal conditions for development of weeds, plant diseases and pests. Humogley represents an unfavorable environment for the cultivation of perennial crops.

Overburden soil in mining basin Kolubara belongs to deposol type and it is characterized with low organic matter, low nutrients contents and poor structure, but good water balance. In 2014, there was high precipitation in this region during whole vegetative period. Figure 1 presents yields during three years on the overburden soil from mining basin in Kolubara.

No significant difference was noted in tillering between the fertile soil in Vršac, ash from thermal power plant Nikola Tesla, overburden in Kolubara and degraded soil in Kozjak. The biggest variation in the function of substrates is noted in plant height. Crops on the overburden in Kolubara and ash in TENT $B$ have not reached a height of 1 meter in 1st year and were characterized with wider leaf and stems than crops on plantations in Vrsac and Kozjak where they were grown on fertile soil and degraded cambisol (Figures 2, 3, 4, 5).

According to the results obtained from these experimental plots, an agreement on the establishment of 


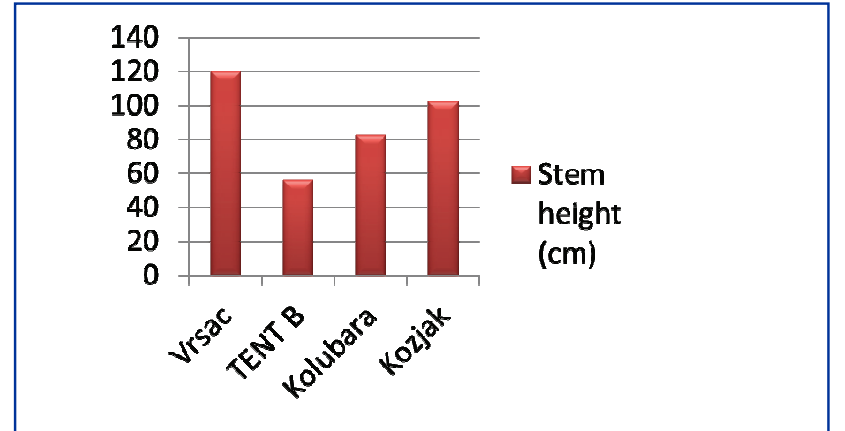

Figure 2 Stem height

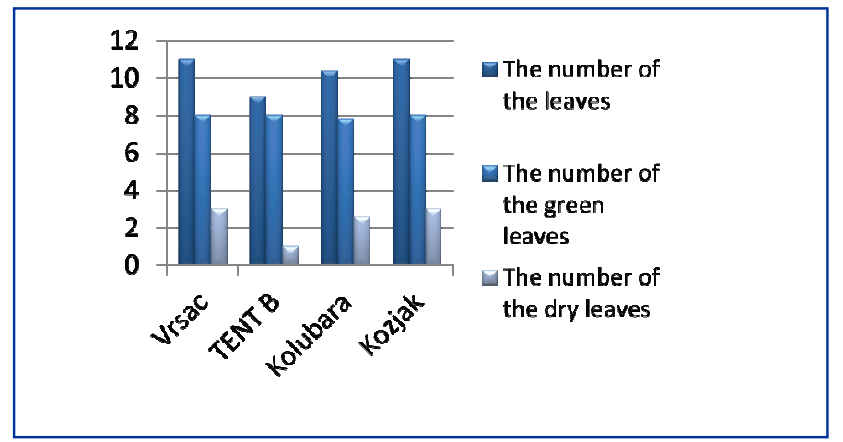

Figure $3 \quad$ Number of leaves at different locations

experimental polygon on unused land of $6^{\text {th }}$ and $7^{\text {th }}$ quality class at the territory of Mačva was signed between the Ministry of Agriculture and Environmental Protection and the Research and Development Centre of the Faculty, in accordance with the objectives of the national strategy for sustainable development of agriculture in 2014 to ensure the efficient use of land of poor quality, efficient land management and increase the availability of land resources and a higher degree of agricultural land use.

\section{Remediation}

The analysis of soil and dry Miscanthus biomass grown on degraded areas has confirmed literature data on remediation

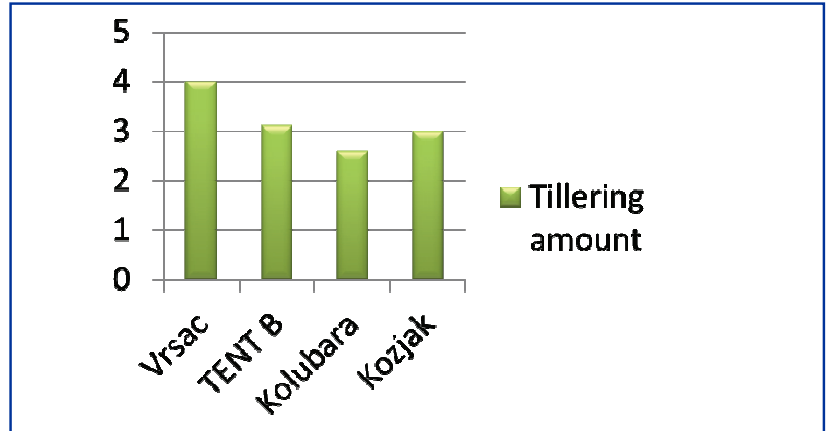

Figure 4 Tillering amount

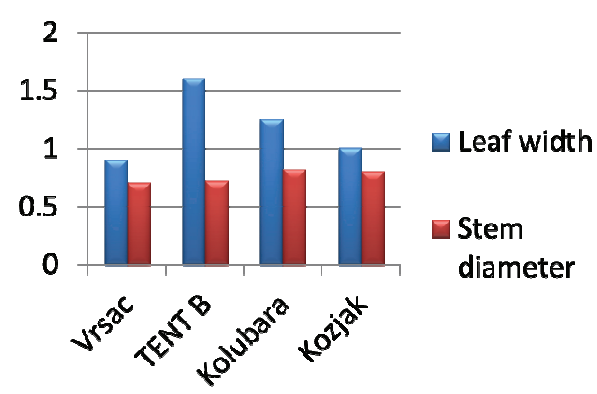

Figure 5 Leaf width and stem diameter

characteristics of Miscanthus (Pidlisnyuk et al., 2014; Wanat 2015a; 2015b). Remediation process of industrially degraded soils was started, especially on overburden from mining basin Kolubara and ash from power plant Nikola Tesla.

Table 9 presents morphological characteristics of Miscanthus on fertile soil, ash and overburden with growth stimulator (acetylsalicylic acid), fertilizer, and heavy metals. Reduction in height of stems by $30 \%$ on average has been noted with heavy metals in the substrate; the other parameters were not significantly changed. The height of the stem on the fertile soil with heavy metals was $26.7 \%$ lower than the control group, although some stems have reached a height of one meter which was not the case on

Table 9 Morphological characteristics of Miscanthus $\times$ gigantheus

\begin{tabular}{|c|c|c|c|c|c|c|c|c|}
\hline & $\begin{array}{l}\text { Stem height } \\
\text { in } \mathbf{~ c m ~}\end{array}$ & $\begin{array}{l}\text { Number of } \\
\text { the leaves }\end{array}$ & $\begin{array}{l}\text { Length of green } \\
\text { part of a leaf in } \mathrm{cm}\end{array}$ & $\begin{array}{l}\text { Leaf width } \\
\text { in } \mathrm{cm}\end{array}$ & $\begin{array}{l}\text { Stem diameter } \\
\text { in } \mathbf{~ c m ~}\end{array}$ & $\begin{array}{c}\text { Green leaf } \\
\text { No. }\end{array}$ & $\begin{array}{l}\text { Dry leaf } \\
\text { No. }\end{array}$ & $\begin{array}{l}\text { Tillering } \\
\text { amount }\end{array}$ \\
\hline \multicolumn{9}{|c|}{ Soil } \\
\hline Control & 73.67 & 10.33 & 29.00 & 0.90 & 0.73 & 9.00 & 1.33 & 4.00 \\
\hline $\mathbf{H M}^{*}$ & 54.00 & 9.33 & 20.67 & 1.06 & 0.63 & 8.67 & 0.67 & 2 \\
\hline HMS** & 80.67 & 9.67 & 39.50 & 1.06 & 0.80 & 9.00 & 0.67 & 4.33 \\
\hline \multicolumn{9}{|c|}{ Ash } \\
\hline Control & 87.00 & 10.33 & 32.00 & 0.93 & 0.76 & 8.67 & 1.67 & 2.00 \\
\hline HM & 76.25 & 9.50 & 35.00 & 0.80 & 0.65 & 8.50 & 1.00 & 3.50 \\
\hline HMS & 82.30 & 9.00 & 31.33 & 0.83 & 0.70 & 7.00 & 2.00 & 1.67 \\
\hline \multicolumn{9}{|c|}{ Overburden } \\
\hline Control & 54 & 10 & 22 & 0.95 & 0.65 & 8.00 & 2.00 & 2.00 \\
\hline HM & 36.5 & 9.00 & 41.00 & 0.60 & 0.45 & 8.00 & 2.50 & 4.00 \\
\hline HMS & 47.75 & 6.00 & 29.25 & 0.53 & 0.40 & 5.5 & 2.30 & 1.00 \\
\hline
\end{tabular}

${ }^{*} \mathrm{HM}$ - heavy metals, ${ }^{*} \mathrm{HMS}$ - heavy metals and stimulator of grow 
the plantation where only fertilization and stimulation treatments were applied (control group). Number of leaves is slightly smaller in the pots with cadmium and nickel, about $10 \%$. The addition of heavy metals in the fertilized soil, with acetylsalicylic acid, results in an increase of stem height by $9 \%$.

The table shows that Miscanthus can be grown on ash with watering in the summer months. The presence of heavy metals has the most influence on the stem height, which is, on average, $12.6 \%$ lower than control group. The intensity of tillering was even higher in the pots with heavy metals. Length of leaves and their number remained almost unchanged.

Addition of heavy metals on overburden has caused the stem height reduction by $32.4 \%$, the average number of leaves decreased by $10 \%$, while the intensity of tillering increased by $100 \%$. The data presented in the table 9 indicate that the cultivation of Miscanthus on ash and overburden with the addition of heavy metals and fertilizer is possible.

The content of cadmium in the dry residue is shown in the Figure 6. Cadmium content was seven times higher in the experimental group (228.4 ppm $\mathrm{CdCl}_{2}$ ) than in the rest of the dry Miscanthus matter grown on substrates without the addition of cadmium. Miscanthus on the ashy substrate absorbs three times higher amount of $\mathrm{Cd}$ than Miscanthus on the soil and about 200\% more than the one on the overburden. Stimulator of growth has significantly contributed to increasing amounts of $\mathrm{Cd}$ in the soil and overburden.

Figure 7 presents nickel content in the dry residue. The maximum amount of $\mathrm{Ni}$ was absorbed onto the overburden without added growth stimulators, and with acetylsalicylic acid, that amount was decreased although the stems were $30 \%$ higher. The amount of absorbed $\mathrm{Ni}$ is increased by the



Figure 6 Content of the cadmium in the dry residue

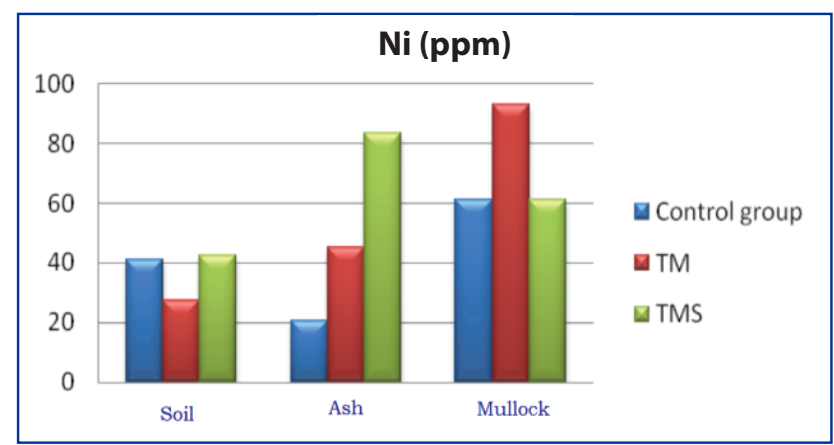

Figure $7 \quad$ Nickel content in the dry residue adding of growth stimulator on the soil and ashes while on the overburden, the rate of nickel is decreasing.

The amount of absorbed $\mathrm{Cd}$ on the soil and overburden, with the addition of acetylsalicylic acid, was 3 times higher than on ash. Miscanthus grown on ash without stimulator absorbs 3 times larger amount of cadmium than the experimental group with acetylsalicylic acid, unlike groups of Miscanthus on soil and overburden. In the pots with growth stimulator, the amount of absorbed Cd increased more than three times on the soil and about two times on the overburden.

The presented data indicate that the cultivation of Miscanthus on ash and overburden with the addition of heavy metals and fertilizer is possible. Cultivation of Miscanthus on polluted or degraded soil contributes to remediation of soil and water, biomass production as an annual-renewable energy, alleviates climate change and helps preservation and enhancement of habitat which effect biodiversity. Plantations of Miscanthus show big ecological efficiency due to these characteristics of plants (Milanović et al., 2012).

\section{Conclusions}

Field experiments with the aim to perceive dynamics of development of aboveground biomass of Miscanthus in agro ecological conditions of the Republic of Serbia, on low quality soil and on anthropogenic degraded soil show high possibility to produce viable rhizomes of Miscanthus $x$ giganteus on degraded soil. The quality of biomass depends on the date of harvest and growing conditions, while irrigation and fertilization is the most important for the quantity, although the results vary in different locations.

By applying the $T$ test, it was found that cultural practices affect the strength of tillering and plant cover while there is no statistically significant relationship between agricultural practices and the germination rate of Miscanthus.

The highest biomass yield in the cultivation of Miscanthus on humogley has been reached in the treatment with planting density of 2 rhizomes $\mathrm{m}^{-2}$ and the amount of ingested nitrogen of $50 \mathrm{~kg} \cdot \mathrm{ha}^{-1}$. Larger amounts of nitrogen increase costs of plantation establishing and do not significantly affect the amount of biomass. Variations in biomass amount were in function of soil type, planting density and annual climate.

It is not necessary to perform mechanical control of weeds or apply herbicides from the second year of plantation development. Harvest should be done as late as possible (March), immediately before the start of a new vegetative cycle with the lowest percentage of moisture. Fertilization should be carried out immediately after harvest, thereby ensuring a sufficient amount of nitrogen required for the next cycle of vegetation.

Miscanthus on the overburden is most sensitive to the presence of additional amount of heavy metals. Addition of heavy metals on overburden has caused the stem height reduction by $32.4 \%$, but the intensity of tillering increased by $100 \%$. Addition of heavy metals in the fertilized soil causes a reduction of stem height by $30 \%$. Addition of heavy metals on the fertilized soil, with acetylsalicylic acid led to increase of stem height by $9 \%$. In the pots with growth stimulator, the amount of absorbed $\mathrm{Cd}$ increased more than three 
times on the soil and about two times on the overburden. The amount of absorbed $\mathrm{Ni}$ is increased by adding of growth stimulator on the soil and ashes while the overburden rate of the nickel is decreasing.

The fertile agricultural land as well as moderate degraded areas provide suitable conditions for miscanthus biomass and viable rhizomes production for energy and ecoremediation purposes. Production of agro-energy crops may improve the quality of life in rural areas, reduce poverty and prevent social and environmental degradation supporting the diversification of rural economy.

\section{Acknowledgments}

This research was supported by the Ministry of Education, Science and Technological Development of the Republic of Serbia and the Electric Power Industry of Serbia through the project TR31078 "Ecoremediation of degraded areas through agro-energy crops production".

\section{References}

CHRISTIAN, D.G. - RICHE, A.B. - YATES, N.E. 2008. Growth, yield and mineral content of Miscanthus giganteus grown as a biofuel for 14 successive harvests. In Industrial, vol. 28, pp. 320-327

CLIFTON-BROWN, J.C. - JONES, M.B. - BREURER, J. 2001. Yield performance of $M$. giganteus during a 10 year field trial in Ireland. Aspects of Applied Biology. In Biomass and energy crops II, vol. 65, pp. 153-160.

DANALATOS, N.G. - ARCHONTOULIS, S.V. - MITSIOS, I. 2007. Potential growth and biomass productivity of Miscanthus $\times$ giganteus as affected by plant density and $\mathrm{N}$-fertilization in central Greece. In Biomass and Bioenergy, vol. 31, no. 2-3, pp. 145-152.

DRAŽIĆ, G. - MILOVANOVIĆ, J. - IKANOVIĆ, J. - GLAMOČLIJA, Đ. 2010. The effect of agroecological factors on the production of biomass Miscanthus giganteus. In Archives of Agricultural Sciences (in Serbian), vol. 71, pp. 81-85.

DRAZIC, G. - MILOVANOVIC, J. - ARANDJELOVIC, M. 2014. Biomass as driwing force for rural development-miscanthus best practice. In Agriculture and Forestry, vol. 60, no. 2, pp. 115-124.

DŽELETOVIĆ, Ž. 2010. Effect of nitrogen and plantation density on morphological characteristics and yield of biomass Miscanthus $x$ giganteus Greef et Deu. PhD thesis, Faculty of Agriculture, Belgrade ENERGY BALANCE OF THE REPUBLIC OF SERBIAN 2014. godinu. http://www.mre.gov.rs/doc/efikasnost/izvori/7\%20IZMENA\%20 ENERGETSKOG\%20BILANSA\%20REPUBLIKE\%20SRBIJE\%20ZA\%20 2014.doc., 18.07.2015

IKANOVIC, J. - DRAŽIĆ, G. - POPOVIC, V. - RAJIĆ, Z. 2015. The bioenergy challenge and efficient use of land resources. In Energy, ekonomy, ekology (in serbian), vol. 1-2, pp. 96-102.
IKANOVIC, J. - POPOVIC, V. - JANKOVIC, S. - RAKIC, S. - DRAZIC, G. - ZIVANOVIC, LJ. - KOLARIĆ, LJ. - LAKIĆ, Ž. 2015. Miscanthus biomass production growth on degraded land (in Serbian). Proceedings of the XXIX Advising agronomists, veterinarias and technologists, The Institute PKB Agroekonimik, pp. 115-124. ISSN 0354-1320.

JEŻOWSKI, S. 1994. Miscanthus sinensis "Giganteus" - a grass for industrial and energetic purpose. In Genet. Pol., vol. 35A, pp. 372-379.

LEWANDOWSKI, I. - CLIFTON-BROWN, J.C. - SCURLOCK, J.M.O. HUISMAN, W. 2000. Miscanthus: European experience with a novel energy crop. In Biomass and Bioenergy, vol. 19, no. 4, pp. 209-227. MILOVANOVIĆ, J. - DRAŽIĆ, G. - IKANOVIĆ, J. - JUREKOVA, Z. RAJKOVIĆ, S. 2012. Sustainable production of biomass through Miscanthus giganteus plantantion development. Annals of Faculty Engineering Hunedoara International Journal of Engineering, vol. 10, pp. 79-82.

NATIONAL ACTION PLAN FOR THE USE OF RENEWABLE ENERGY SOURCES OF SERBIAN. 2013. Ministry of Energy, Development and Environment, Belgrade.

PIDLISNYUK, V. - STEFANOVSKA, T. - LEWIS, E. - ERICKSON, L. - DAVIS, L. 2014. Miscanthus as a Productive Biofuel Crop for Phytoremediation. In Critical Reviews in Plant Sciences, vol. 33, pp. 1-19.

STRATEGY OF AGRICULTURE AND RURAL DEVELOPMENT OF SERBIAN. 2014-2024. Ministry of Agriculture, Forestry and Water Management of the Republic of Serbia.

ENERGY DEVELOPMENT STRATEGY OF THE REPUBLIC OF SERBIA until 2025 with projections until 2030. Official Gazette no. 57/11, 80/11 - correction, 93/12 and 124/12)

WANAT, N. 2015. Potential adaptation of Miscanthus $\times$ giganteus for the phytoremediation of a former mine site highly contaminated. https://tel.archives-ouvertes.fr/tel-00809037/document, 7.7.2015.

WANAT, N. - AUSTRUY, A. - JOUSSEIN, E. - SOUBRAND-COLIN, M. - GAUTIER-MOUSSARD, C. - HITMI, A. 2015. Phytoremediation of a Former Mine Site: Miscanthus $\times$ giganteus, a Potential Tool, Heavy metals in sediments and remediation technologies, http://www.iaea.org/inis/collection/NCLCollectionStore/_ Public/41/131/41131224.pdf, 7.7.2015.

WORLD ENERGY OUTLOOK. http://www.worldenergyoutlook.org/ publications/weo-2014/, 10.08.2015.

ENERGY LAW. “RS Official Gazette”, 2014, no. 145.

ŽIVANOVIĆ, LJ. - IKANOVIĆ, J. - POPOVIĆ, V. - SIMIĆ, D. - KOLARIĆ, LJ. V - MAKLENOVIĆ, V. - BOJOVIĆ, R. - STEVANOVIĆ, P. 2014. Effect of planting density and supplemental nitrogen nutrition on the productivity of miscanthus. In Romanian agricultural research, 2014, no. 31, pp. 291-298. 